\title{
Outbreak of Measles in vaccinated population in Southeastern Nigeria
}

\author{
*1Shenge, J. A., ${ }^{2}$ Odaibo, G. N., and ${ }^{2}$ Olaleye, D. O. \\ ${ }^{1}$ Department of Biological Sciences, Dominican University, Ibadan, Nigeria \\ ${ }^{2}$ Department of Virology, College of Medicine, University of Ibadan, Ibadan, Nigeria \\ *Correspondence to: jadamma@yahoo.com
}

\begin{abstract}
:
Background: Outbreaks of respiratory disease, febrile illness and rash occurred in two adjoining rural communities of Imo State, Southeastern, Nigeria, at different times between 2006 and 2020. Laboratory investigation was carried out to determine the aetiological agent of the outbreak.

Methodology: Oropharyngeal swabs were collected from 6 individuals showing symptoms of disease, within 3-4 days of appearance of rash. Venous blood samples were also collected from a total of 41 symptomatic persons, their contacts and individuals with resolved infections. Swabs were inoculated into Vero, HEp-2c, B95a and MDCK cell lines. Sera were analyzed using enzyme-linked immunosorbent assay (ELISA) for immunoglobulin $G$ and $M$ to rubella and measles viruses, while immunofluorescence assay was used to detect Lassa fever virus immunoglobulins. Descriptive data were analyzed using the Statistical Package for the Social Sciences (SPSS).

Results: Four of the $6(66.7 \%)$ swab samples showed viral activity or cytopathic effect characterized by clumping of cells in Vero cells while $2(33.3 \%)$ in Hep-2c characterized by rounding up of cells. Thirty-nine $(95.1 \%)$ sera were positive for measles IgG while $13(31.7 \%)$ were positive for IgM. Thirty-six $(87.8 \%)$ sera were positive for rubella IgG but none was positive for IgM. None of the sera was positive for Lassa fever virus IgG and IgM. Conclusion: Measles virus was responsible for the outbreak among previously vaccinated population in the communities, while Rubella and Lassa fever viruses were excluded as the etiological agents of the outbreak.
\end{abstract}

Keywords: Epidemics; IgG and IgM; Cell lines; Vaccination; Measles virus

Received Oct 21, 2020; Revised Jan 11, 2021; Accepted Mar 27, 2021

Copyright 2021 AJCEM Open Access. This article is licensed and distributed under the terms of the Creative Commons Attrition 4.0 International License <a rel="license" href="http://creativecommons.org/licenses/by/4.0/", which permits unrestricted use, distribution and reproduction in any medium, provided credit is given to the original author(s) and the source. Editor-in-Chief: Prof. S. S. Taiwo

\section{Épidémie de rougeole dans la population vaccinée du sud-est du Nigéria}

\author{
${ }^{* 1}$ Shenge, J. A., ${ }^{2}$ Odaibo, G. N., et ${ }^{2}$ Olaleye, D. O. \\ ${ }^{1}$ Département des sciences biologiques, Université dominicaine, Ibadan, Nigéria \\ ${ }^{2}$ Département de virologie, Collège de médecine, Université d'Ibadan, Ibadan, Nigéria \\ *Correspondance à: jadamma@yahoo.com
}

\begin{abstract}
Abstrait:
Contexte: Des flambées de maladies respiratoires, de maladies fébriles et d'éruptions cutanées sont survenues dans deux communautés rurales voisines de l'État d'Imo, dans le sud-est du Nigéria, à des moments différents entre 2006 et 2020. Une enquête en laboratoire a été menée pour déterminer l'agent étiologique de l'épidémie. Méthodologie: Des écouvillons oropharyngés ont été prélevés sur 6 individus présentant des symptômes de maladie, dans les 3 à 4 jours suivant l'apparition de l'éruption cutanée. Des échantillons de sang veineux ont également été prélevés sur un total de 41 personnes symptomatiques, leurs contacts et des personnes souffrant d'infections résolues. Des écouvillons ont été inoculés dans des lignées cellulaires Vero, HEp-2c, B95a et MDCK. Les sérums ont été analysés en utilisant un test immuno-enzymatique (ELISA) pour les immunoglobulines $\mathrm{G}$ et $M$ contre les virus de la rubéole et de la rougeole, tandis que le test d'immunofluorescence a été utilisé pour détecter les immunoglobulines
\end{abstract}


du virus de la fièvre de Lassa. Les données descriptives ont été analysées à l'aide du progiciel statistique pour les sciences sociales (SPSS).

Résultats: Quatre des 6 échantillons sur écouvillon $(66,7 \%)$ ont montré une activité virale ou un effet cytopathique caractérisé par l'agglutination des cellules dans les cellules Vero, tandis que 2 (33,3\%) dans Hep-2c étaient caractérisés par un arrondissement des cellules. Trente-neuf $(95,1 \%)$ sérums étaient positifs pour les IgG contre la rougeole tandis que $13(31,7 \%)$ étaient positifs pour les IgM. Trente-six $(87,8 \%)$ sérums étaient positifs pour les IgG contre la rubéole, mais aucun n'était positif pour les IgM. Aucun des sérums n'était positif pour les IgG et IgM du virus de la fièvre de Lassa.

Conclusion: Le virus de la rougeole était responsable de l'épidémie parmi la population précédemment vaccinée dans les communautés, tandis que les virus de la rubéole et de la fièvre de Lassa ont été exclus comme agents étiologiques de l'épidémie.

Mots clés: épidémies; IgG et IgM; Lignées cellulaires; Vaccination; Virus de la rougeole

\section{Introduction:}

Emerging infectious diseases have been the most implicated in recent outbreaks, affecting human and animal lives in very negative ways, globally. Viruses survive only in living cells essentially to create more particles by replication, which involves taking over the host cell protein and genetic material - synthetic processes, to produce virus related nucleic acid and proteins as new viruses (1). If not curtailed, the spread of viral disease in a population may become extensive, and most viruses especially the enteroviruses are known to survive harsh environmental conditions. In endemic areas, viruses are continuously shed into the environment and this can give rise to an outbreak once entrance is gained into a suitable host (2).

Most RNA viruses of the families; Orthomyxoviridae, Paramyxoviridae and Corona viridae have been implicated in viral disease outbreaks, with pandemic potentials. In humans especially, respiratory viruses are one of the most important causative agents of diseases causing acute respiratory infections (ARIs), particularly among children less than five years, often with high morbidity and mortality worldwide (3). The appearance of new diseases and syndromes as well as the resurgence of old ones can be associated to a large extent with ecological changes that favour increased vector densities, coupled with human activities that spread infectious agents and introduce them into areas where they had been absent (4).

Many viral infections and their emergence are brought about by a combination of factors which increase human exposure to viral pathogens (5). Some of these factors include human behaviours such as environmental changes, food production, socio-economic and demographic factors, health care delivery, travel and commerce (6). Ecological factors also play a tremendous role in disease distribution and these changes at one point or the other encourage migration of virus reservoirs (such as wild birds and bats) which transmit viral diseases to both humans and animals in their course of migration (7). Recurrence of epidemics and pandemics of viral origin in a number of cases occur as a result of some other factors which may be genetic changes or mutation (variations) in the genome of viruses or adaptation to new hosts (8).

When a virus succeeds in establishing an infection in the host, a viral disease results through one of the following; destruction of the host cells (cytolytic effects), continuous production of virus by budding in which the virus maintains in a steady state with the host or a chronic and often fatal condition arises due to integration of viral genetic material into the genome of the host, leading to transformation of the host cells (8). An infection is a condition in which viruses, bacteria, fungi or parasites enter the body and cause a state of disease (9). They damage cells of the body by adhering to and damaging the cell walls, releasing toxic substances or causing allergic reactions (10).

Majority of viral disease outbreaks are linked to water as the source. Schuster and colleagues (11) analyzed waterborne outbreaks and impact of drinking water quality on public health disease burden, and found that many factors such as severe weather or climate change, close proximity to animal populations, treatment system malfunctions, poor maintenance and treatment practices were associated with the reported disease outbreaks resulting from drinking water supplies. Transmission of viral diseases is of public health importance. Direct and indirect contacts between humans and other vertebrates have resulted in serious outbreaks (12). It has been estimated that $60 \%$ of human infections are caused by viruses (13). While some viruses show full spectrum of characteristics that identify them as infectious agents in most viral diseases, others do not. Hence, the aim of this outbreak investigation was to identify the etiological agent of the outbreaks in two rural communities of Imo State, Southeastern, Nigeria, with laboratory investigations including serological tests, virus 
isolation in cell lines, and immunofluorescent assays.

\section{Materials and method:}

\section{Study area}

This outbreak investigation was carried out in Obowu Local Government Area of Imo State, Nigeria. The area comprises of fourteen communities. It lies on longitude $7^{\circ} 20^{\prime} \mathrm{E}$ and Latitude $5^{0} 30^{\prime} \mathrm{N}$. It is located about $150 \mathrm{~km}$ north of Bonny in Eastern Nigeria, with an estimated population of about 50,000 people as projected from the 2006 census figure (16).

\section{Ethical consideration}

Approval to investigate the outbreaks was obtained from the local councils and the traditional rulers of affected communities. Informed consent of all persons from whom samples were collected was obtained.

\section{Data collection and sample processing}

Data from individuals including records of vaccination and other useful information regarding the outbreak, were collected. These included information on vaccination history, and symptoms observed such as sore throat, cough, catarrh, coryza, myalgia, fever. Oropharyngeal swab samples were collected from 6 persons presenting with fresh symptoms of rash and respiratory infection while venous samples were collected from a total of 41 persons with symptoms, their contacts and individuals with resolved infections.

The swab specimens were collected on swab sticks into sterile cryovials containing PBS and antibiotics as transport medium. The samples were preserved at $-20^{\circ} \mathrm{C}$ until transported with ice packs to the laboratory for analysis. In addition, venous blood samples were collected into sterile EDTA bottles containing anticoagulant from all individuals including those with clinical symptoms, resolved cases and contacts of those with active disease and symptoms. The samples were stored at $4^{\circ} \mathrm{C}$ until transported to the laboratory.

Both blood and oro-pharyngeal samples were transported to Virology laboratory of the University College Hospital, Ibadan, Nigeria, in insulated boxes containing ice-packs to maintain the cold chain. Blood samples were separated and sera stored in new sterile tubes and stored at $-20^{\circ} \mathrm{C}$ pending analyses.

\section{Virus isolation in tissue culture}

Four cell lines were used for the primary isolation and 'passage' of the suspected viral agent from each swab sample. The cell lines included Vero (from African green monkey kidney), HEp-2c (derived from human epithelial cells), MDCK (Mardin-Darbin Canine Kidney cells) and B95a (from kidney of Marmoset Monkey). Each oro-pharyngeal swab sample was diluted and made up to $2.5 \mathrm{ml}$ with maintenance medium and filtered using a $0.2 \mu \mathrm{l} \mathrm{milli-}$ pore filter into new set of pre-labelled Kahn tubes. After filtration, $0.2 \mathrm{ml}$ of each swab sample was inoculated into each cell line after decanting the growth medium. Virus from sample was allowed to adsorb at $37^{\circ} \mathrm{C}$ for one hour, and the appropriate maintenance medium was added to each cell line. The medium of cell control tubes was replaced with maintenance medium.

All the tubes were incubated at $37^{\circ} \mathrm{C}$ and examined daily for evidence of virus growth (cytopathic effect) for seven days. Tubes showing cytopathic effects (CPE) on or before the seventh day were passed into new culture tubes to rule out toxicity or to increase the virus titre. Similarly, tubes without obvious CPE were also re-passaged. Any culture tubes without CPE after the first blind 'passage' and kept for more days were regarded as negative. The tubes showing cytopathic effects (CPE) were passed up to four times into $25 \mathrm{~cm}^{3}$ culture flasks to increase the virus titre and yield. The supernatant fluid of each flask was collected and stored in aliquots at $-80^{\circ} \mathrm{C}$ for further analysis.

\section{Detection of Measles immunoglobulin G \& M}

Measles IgG and $M$ was detected using Orgenics ImmunolisaTM kit. All the reagents and samples were allowed to attain room temperature on the bench. The incubator was set at $37^{\circ} \mathrm{C}$. The microplate R1 was labelled with sample numbers accordingly, including the four control wells. Then, $100 \mu$ l of serum dilution solution R2 was added into all the wells and $5 \mu \mathrm{l}$ of each sample into appropriate wells. Also, $5 \mu \mathrm{l}$ of positive control R3 and $5 \mu$ l of cut off serum R5 were added in duplicate, and $5 \mu$ l of negative control was dispensed. The microplate was covered with sealing sheet and incubated at $37^{\circ} \mathrm{C}$ for $45 \mathrm{mins}$. After incubation, $100 \mu \mathrm{L}$ of $1 \mathrm{gG}$ conjugate solution R9 was immediately added into each well. The microplate was sealed again and incubated at $37^{\circ} \mathrm{C}$ for $30 \mathrm{~min}$. This was followed by washing of the plate with $0.3 \mathrm{ml}$ of washing solution R13. $100 \mu$ of substrate solution R11 was added into each well. The plate was sealed and incubation done at room temperature for $20 \mathrm{mins}$. The seal was removed and $50 \mu$ l of stopping solution R12 added into all the wells. Reading of the plate was carried out with a spectrophotometer at 450/620nm.

The mean OD (Optical Density) for each 
control (positive, negative and cut off) was calculated as; cut off control $=<0.7 \times$ (OD Positive Control)/>1.5 x (OD Negative Control), and antibody index = sample OD/cut off serum mean OD x 10. For validity of the result, OD for positive control must be $>0.9$ while that of negative control must be $<0.55$. The antibody index for positive samples was $>11$ while that of negative samples was $<9$. Samples with IgG and IgM index values of 9 - 11 were equivocal. Hence, samples with index values above 11 are considered as having IgG or IgM specific antibodies against measles, and the final result was based on these values.

\section{Determination of Rubella immunoglobulin G \& M by IgM 'capture'.}

Using the Dia-Pro Diagnostic Bioprobes serological reagents, samples were diluted in ratio $1: 101$ with the sample diluent $(10 \mu l$ sample $+1000 \mu$ liluent) and dispensed accordingly. Ninety-six well microplate was covered with a sealer and incubated for $60 \mathrm{~min}$ at $37^{\circ} \mathrm{C}$. Then $100 \mu$ l of diluted $\mathrm{Ag} / \mathrm{Ab}$ (immune complex) was added to all well except $A 1$. The plate was incubated at $37^{\circ} \mathrm{C}$ for $60 \mathrm{~min}$. After removing the sealer, the microplate was washed five times using the automatic washer. This was followed by addition of $100 \mu \mathrm{l}$ of the chromogen/substrate mixture into the wells, A1 included. The plate was incubated the third time at room temperature for $20 \mathrm{~min} .100 \mu \mathrm{l}$ stop solution was added to all wells, A1 included. The Microplate was read at $450 \mathrm{~nm}$ and $620-630 \mathrm{~nm}$, blanking the $A 1$ well.

\section{Detection of Lassa fever immunoglobulin G \& M by immunofluorescence assay (IFA)}

The IFA slides and samples were allowed to attain room temperature before use. Samples were diluted in ratio $1: 40$ by adding $5 \mu$ of each serum sample into $195 \mu$ l of PBS in a pre-labeled microplate. Then, $20 \mu$ l of 1:40 dilution of specimen was dispensed accordingly into the wells of the slides. Controls were dispensed into the corresponding wells. The IgM slides were placed in a tray and incubated at $37^{\circ} \mathrm{C}$ in humidified chamber for 2 hours while IgG slides were incubated for one hour. After incubation, slides were flooded with PBS and rocked for $10 \mathrm{~min}$ on a rocker. Both slides were air dried and respective Fluorescein isothiocyanate (FITC) conjugated-sheep antihuman Ig (Murex Diagnostic Ltd., Dartford, England) added into all the wells. The second incubation was carried out at $37^{\circ} \mathrm{C}$ for $30 \mathrm{~min}$. Slides were flooded and washed for another $10 \mathrm{~min}$ on a rocker. After washing, each slide was covered with a cover slip and slides mounted on the fluorescence microscope for microscopic examination.

\section{Statistical analysis}

Descriptive data were analyzed using Statistical Package for Social Sciences (SPSS).

\section{Results:}

In the two affected rural communities, 41 persons were serologically investigated, 14 (34.1\%) males and 27 (65.9\%) females, all aged between 3 months and 50 years. Six $(14.6 \%)$ had clinical symptoms at the time of the outbreak investigation; 28 (68.3\%) had resolved symptoms while $7(17.1 \%)$ contacts reported no symptoms. Forty $(97.6 \%)$ were previously vaccinated while $1(2.4 \%)$ was yet to be vaccinated.

Of the 6 oropharyngeal swab samples, 4 $(66.7 \%)$ showed evidence of viral growth (clumping of infected cells) in Vero, 2 (33.3\%) samples showed CPE (rounding up of cells) in HEp-2c, and none in B95a and MDCK cell lines. This confirmed that virus was implicated in the outbreak. Serum samples of 39 (95.1\%) out of 41 subjects were positive for measles IgG as shown in Fig 1. Fig 2 shows the distribution of measles IgM in which 13 (31.7\%) were positive, $12(92.3 \%)$ of whom were positive for both IgG and IgM. Figs 2, 3 and 4 show the number and percentage of positive results within different age groups and gender of the subjects.

Out of the 41 venous blood serum samples, 36 (87.8\%) were positive for Rubella IgG. Fig 5 shows the distribution of Rubella IgG result among 13 (36.1\%) males and 23 (63.9\%) females. All sera were negative for rubella IgM. Furthermore, all samples tested negative for both IgG and IgM to Lassa fever virus. Hence, rubella and Lassa fever viruses were ruled out as the aetiological agents of the outbreak. 

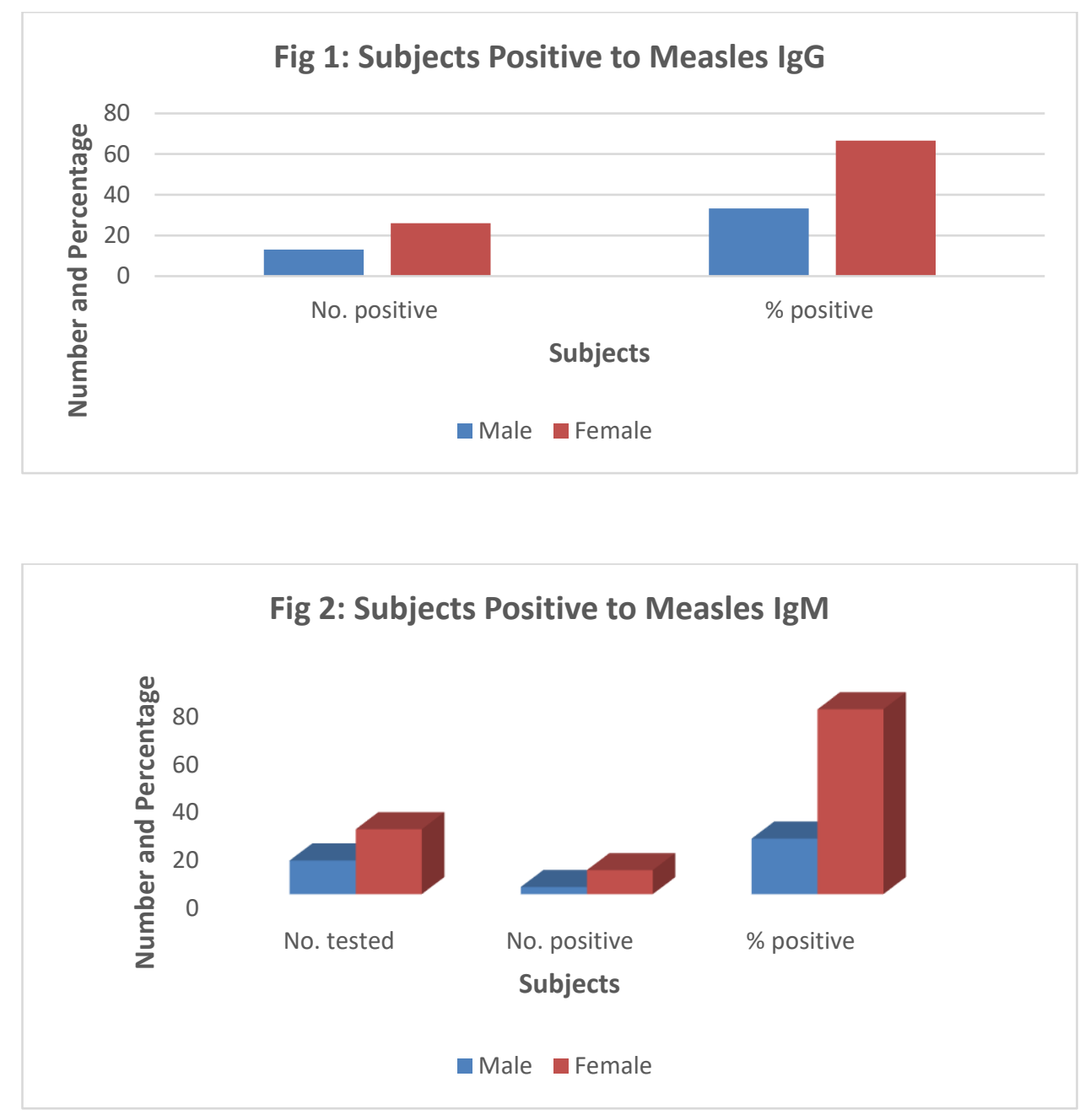

Fig 3: Age Range of Subjects Positive to Measles IgG

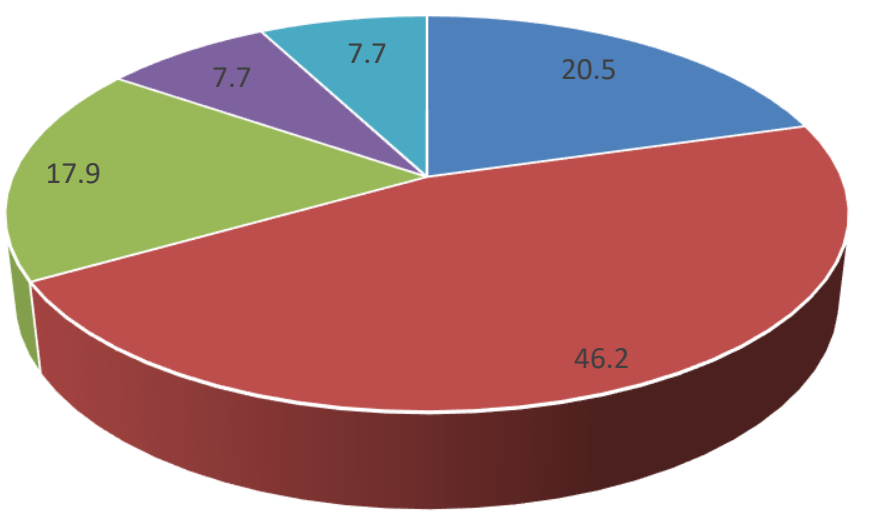

- 0-10

- 11--20

- 21-30

- $31-40$

- 41-50 

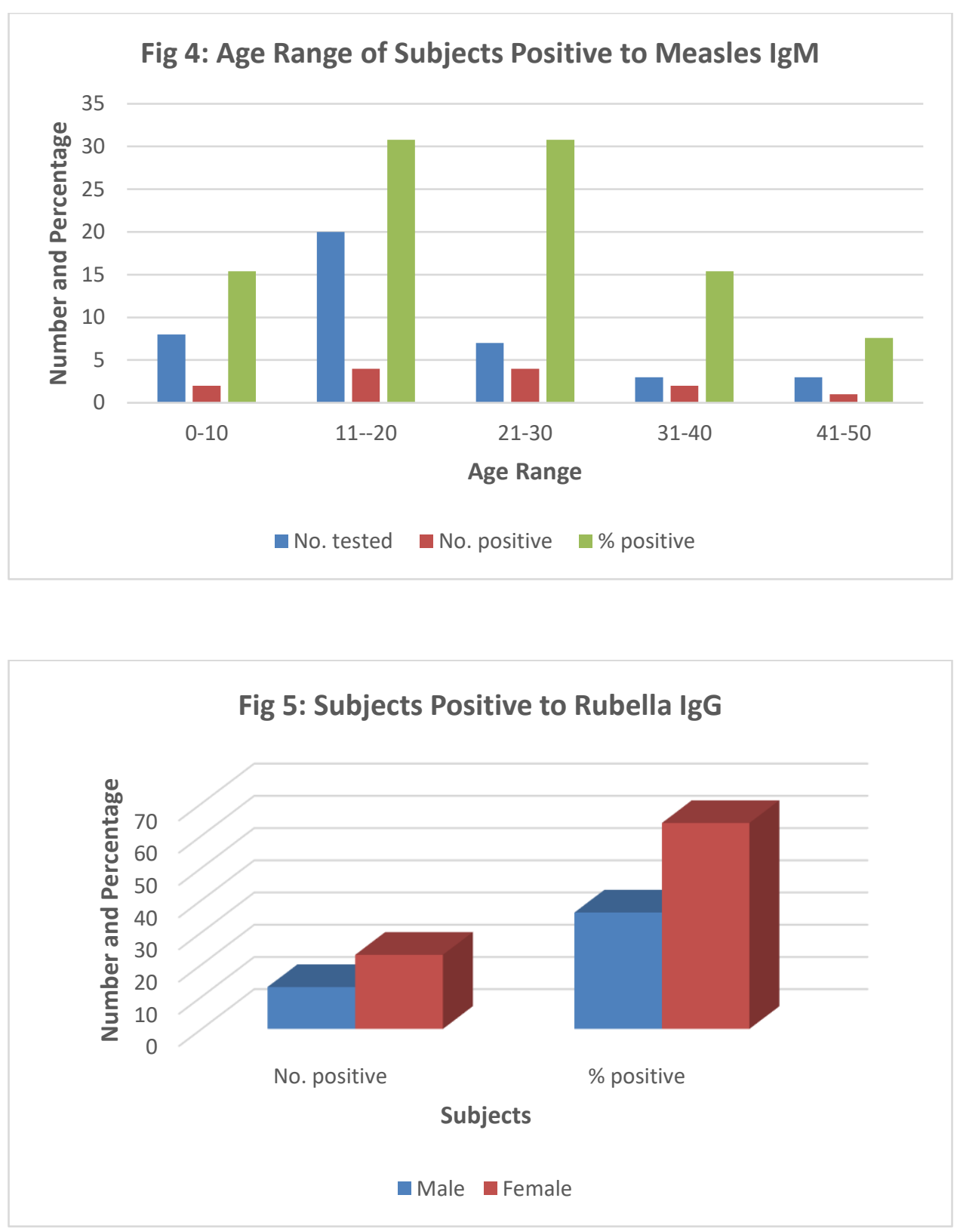

\section{Discussion:}

Measles remains a serious global health challenge, which has persisted even with the availability of a vaccine. It is highly contagious, with increased morbidity and mortality, especially among children less than five years of age. Measles virus is an enveloped, ribonucleic acid virus (RNA) of the genus Morbillivirus and family Paramyxoviridae. There are more than 20 different genotypes that have been isolated in various parts of the world, but with only one serotype (9). In Nigeria, measles, mumps and rubella (MMR) vaccines are given through compulsory routine vaccination exercise to infants at nine months of age (17). It is noteworthy, that this outbreak occurred among vaccinated subjects in those communities as shown by the positive measles IgG results. Measles outbreak among vaccinated children and adults rather poses some questions that require urgent scientific explanation.

Rubella virus was excluded as the causative agent of the outbreak, because none of the samples was positive for rubella IgM, however, $87.8 \%$ tested positive for IgG. These individuals (both gender) in the past received MMR vaccine, which may be responsible for rubella IgG antibody response. The same vaccination was supposedly responsible for the high measles IgG antibody level in the 
population.

In the outbreak, both male and female subjects were infected with measles virus, although more females $(76.9 \%)$ than males $(32.1 \%)$ had active measles (Fig 3 ) and these subjects fell in the age range $0-50$ years, with more measles IgG level (46.2\%) among those aged $11-20$ years (Fig 4), and highest IgM level among age groups $11-20$ and $21-30$ years respectively (Fig 5 ). Forty $(97.6 \%)$ had been vaccinated previously, except $1(2.4 \%)$, a 3month-old baby, yet to receive MMR routine immunization. Those infected had symptoms including febrile illness (high fever), cough, coryza (runny nose), red watery eyes and maculopapular rash which appeared last in most cases.

Immunity conferred by measles through natural infection and vaccination is apparently long-lasting, but some cases of atypical measles have been reported in adolescents who had been vaccinated as children $(14,15)$. This suggests that immunity in the vaccinated population may have waned and therefore not as long-lasting as that following natural infection. It could also mean circulation of a different strain of the measles virus in the population, to which people have little or no immunity. However, it would be potentially serious, if vaccination in children left some people unprotected in teenage and adult life.

Furthermore, among the subjects who showed evidence of measles infection in this investigation, six presented with clinical acute respiratory symptoms and maculopapular rash and they all had positive measles IgM results. Three individuals who tested positive for measles IgM had resolved symptoms, while 4 were part of the 7 contacts who showed no symptom as at the time of sample collection. This suggests that these exposed individuals (contacts)contracted the virus and could be incubating it at the time of sample collection, owing to the contagious nature of measles virus.

Measles is known as a childhood disease (4) but its occurrence twice or more times in a vaccinated population, as seen in this investigation including adults, requires urgent attention. Measles virus infection remains a serious global health problem. Cases of infection caused by wild strain of measles virus in previously vaccinated subjects have been documented (2). As this trend persists, there is need for increased global campaign and awareness on the importance of booster vaccination especially among teenagers and adults who were vaccinated at infancy. This may be one sure way to prevent future measles outbreaks and ensure its eradication in the globe.

\section{Conclusion:}

In conclusion, the cytopathic effects (CPE) on cell cultures implicated virus as the aetiologic agent of the outbreak of an infectious respiratory disease and rashes in the two adjoining communities of Obowu LGA of Imo State, Nigeria. Further serological investigation confirmed measles virus as the cause of the outbreak as indicated by positive IgM antibodies in the infected subjects, which confirmed recent and active infection.

\section{Acknowledgements:}

The authors acknowledge the staff of Department of Virology and other public health officials who assisted during sample collection and analysis of samples.

\section{Conflict of interest:}

Authors declared no conflict of interest.

\section{References:}

1. Alan, J. C. Virus structure and replication: In: Molecular Virology ( $2^{\text {nd }}$ ed). Academic Press, Harcourt Brace and Company, 1997; 1-49.

2. Centre for Disease Control and Prevention (CDC). Mumps epidemic Iowa MMWR Morb Mortal Wkly Rep. 2006; 55 (13): 366-368.

3. Nichols, W. G., Peck Campbell, A. J., and Boeckh, M. Respiratory viruses other than influenza virus: impact and therapeutic advances. Clin Microbiol Rev. 2008; 21 (2): 274-290.

4. Chen, R. T., Goldbaum, G. M., and Wassilak, S. G. F. An explosive point-source measles outbreak in a highly vaccinated population: Mode of transmission and risk factors for disease. Am J Epidemiol. 1989; 129: 173-182.

5. Morse, S. S. Factors in the emergence of infectious diseases. Emerg Infect Dis. 1995; 1 (1): 7-15

6. Gratz, N. G. Emerging and resurging vector-borne diseases. Annu Rev Entomol. 1999; 44: 51-75.

7. Melville, D. S., and Shortridge, K. F. Spread of H5N1, avian influenza virus: an ecological conundrum. Lett Appl Microbial. 2006; 42 (5): 435437.

8. Nugeut, J., Birch-Machin, I., Smith, K. C., et al. Analysis of equid herpes virus 1 strain variation reveals a point mutation of the DNA polymorphism strongly associated with neuropathogenic versus non-neuropathogenic disease outbreaks. J Virol. 2006; 80 (8): 4047-4060.

9. World Health Organizations. Biological; Measles https://www.who.int/biologicals/vaccines/measles/ en/. 11 March 2013.

10. Cheesbrough, M. Medical Laboratory Manual for Tropical Countries. Vol 2. ELBS London, 2007.

11. Schuster, C. J., Ellis, A. G., Robertson, W. J., et al. Infectious disease outbreaks related to drinking water in Canada, 1974 - 2001. Can J Publ Hith. 2005; 96 (4); 254- 258.

12. Turbeville, S. D., Cowan, L. D., and Greenfield, R. A. Infectious Disease Outbreak in Competitive Sports: A Review of Literature. Am J Sports Med. 2006; 34 (11): 1860-1865.

doi: $10.1177 / 0363546505285385$ 
13. Vesperman, J. Revision History. The Gale group Inc. gale, Detroit Gale Encyclopedia of Nursing and Allied Health, 2002.

14. Wong, R. D., Goetz, M. B., Mathisen, G., et al. Clinical and laboratory features of measles in hospitalized adults. Am J Med. 1993; 95: 377-383.

15. Davidkin, S., Jokinen, M., Broman, P., et al. Persis- tence of measles, mumps, and rubella antibodies in an MMR-vaccinated cohort: a 20-year follow-up J Infect Dis. 2008; 197 (7): 950-956

16. National Population Commission. Nigeria National Census, 2006.

17. World Immunization Chart. Updated December, 2020. www.iamat.org. 